\title{
Research Article \\ Expression and Hydroxylamine Cleavage of Thymosin Alpha 1 Concatemer
}

\author{
Liang Zhou, Zong-Teng Lai, Min-Kan Lu, Xing-Guo Gong, and Yi Xie \\ Room 345, College of Life Sciences, Zhejiang University, Hangzhou 310058, China \\ Correspondence should be addressed to Xing-Guo Gong, gongxg@zju.edu.cn
}

Received 3 December 2007; Revised 21 February 2008; Accepted 15 June 2008

Recommended by Nina Prak

\begin{abstract}
Human thymosin alpha $1(\mathrm{~T} \alpha 1)$ is an important peptide in the development and senescence of immunological competence in human, and many studies have reported the expression of this peptide. In this study, we designed and synthesized the T $\alpha 1$ gene according to the $E$. coli codon usage preference and constructed a $6 \times \mathrm{T} \alpha 1$ concatemer. The latter was inserted into an $E$. coli expression vector pET-22b (+), and transformed into E. coli BL21 (DE3). After induction with IPTG, the concatemer protein was successfully expressed in E. coli then cleaved by hydroxylamine to release the T $\alpha 1$ monomer. Gly-SDS-PAGE and mass spectrometry confirmed that the recombinant protein was cleaved as intended. The bioactivity of the T $\alpha 1$ monomer was analyzed by lymphocyte proliferation and by mitochondrial activity in two different tumor cell lines. This study provides a description of the preparation of a bioactive $\mathrm{T} \alpha 1$, which may prove useful in future biomedical research.
\end{abstract}

Copyright (c) 2008 Liang Zhou et al. This is an open access article distributed under the Creative Commons Attribution License, which permits unrestricted use, distribution, and reproduction in any medium, provided the original work is properly cited.

\section{INTRODUCTION}

Thymosin alpha $1(\mathrm{~T} \alpha 1)$, a 28-amino-acid peptide with molecular weight (MW) of $3108 \mathrm{Da}$, was first isolated from calf thymus in 1977 by Goldstein et al. $[1,2]$. T $\alpha 1$ is mainly produced in vivo by thymic epithelial cells and is stable at 80 $90^{\circ} \mathrm{C}[3] . \mathrm{T} \alpha 1$ has no aromatic amino acids (see Figure 1), and $\mathrm{N}$-acetylation is important for protecting towards proteolysis. T $\alpha 1$ plays a role against viral infection, against tumors, and in immunomodulation. Upon stimulation of T $\alpha 1, \mathrm{~T}$ cells become mature in vitro and express IL-2, IL-2R, and CD2 $[4,5] . ~ T \alpha 1$ inhibits viral replication at least in hepatitis virus B-transfected HepG2 tumor cells [6, 7]. In addition, $\mathrm{T} \alpha 1$ antagonizes $\mathrm{T}$ cell apoptosis induced by dexamethasone, CD3 monoclonal antibody treatment [8], or addition of sera from tumor-bearing mice [9]. It also downregulates tumor weight in mice [10], enhances major histocompatibility complex (MHC) class I antigen expression in tumor cells and antigen-presenting cells [11-13], and partly restores cellular immunity [14]. T $\alpha 1$ is used in combination with IFN- $\alpha$ for patients with chronic hepatitis virus $\mathrm{B}$ or $\mathrm{C}$ infection $[15,16]$. $\mathrm{T} \alpha 1$ is used to reduce adverse effects from chemotherapy or radiotherapy [17]. Recently, T $\alpha 1$ has even been used as an adjuvant for vaccines against influenza and hepatitis B [18].
In the past two decades, although the successful expression of the recombinant $\mathrm{T} \alpha 1(\mathrm{r} \mathrm{T} \alpha 1)$ and Prothymosin (thymosin comprises the N-terminus of Prothymosin) in Escherichia coli has been reported $[19,20]$. However, T $\alpha 1$ was expressed with a fusion protein or in a concatemer form $[21,22]$. The expression of the $\mathrm{T} \alpha 1$ monomer peptide has not been reported, because it is difficult to extract the micromolecular peptide from the fermentation broth. The fusion protein must be removed because fusion protein could influence the bioactivity of the peptide. The concatemer protein has not been processed further. All of these issues made it difficult to prepare active recombinant $\mathrm{T} \alpha 1$. In this study, we have expressed $\mathrm{T} \alpha 1$ concatemer protein and cleaved the concatemer protein with hydroxylamine to obtain active T $\alpha 1$ monomer peptide.

\section{MATERIALS AND METHODS}

\subsection{Materials}

The pET-22b (+) vector, E. coli BL21 (DE3) (hsdS gal [ $\lambda$ cIts857 ind1 Sam7 nin5 lacUV5-T7]), the HepG2 liver carcinoma cell line, and the SPC-A-1 lung carcinoma cell line were kindly provided by Institute of Biochemistry 


$\quad 5$
Ac-Ser-Asp-Ala-Ala-Val-Asp-Thr-Ser-Ser-Glu-Ile-Thr-Thr-Lys-Asp-Leu-Lys-Glu-Lys-Lys-Glu-Val-Val-Glu-
25
Glu-Ala-Glu-Asn-OH

FIgURE 1: The complete amino acid sequence of $\mathrm{T} \alpha 1$.

and Cell biology (Shanghai, CAS, China). E. coli BL21 cells were maintained in Luria-Bertani (LB). HepG2 and SPC-A-1 cells were cultured in RMPI 1640 medium with $10 \%$ fetal bovine serum in humidified air at $37^{\circ} \mathrm{C}$ with $5 \% \mathrm{CO}_{2}$. Lymphocytes were isolated from adult mouse spleens (BAL/C) and cultured in RMPI 1640 medium with $10 \%$ fetal bovine serum in humidified air at $37^{\circ} \mathrm{C}$ with $5 \% \mathrm{CO}_{2}$. Synthesized $\mathrm{T} \alpha 1$ (Sinopep Pharmaceutical, Inc., Hangzhou, China.) was supplied as purified, endotoxin-free. The synthesized $\mathrm{T} \alpha 1$ and the cleaved $\mathrm{T} \alpha 1$ were dissolved in phosphate-buffered solution (PBS pH 7.2) at $1 \mathrm{mg} / \mathrm{mL}$ (approximately $3 \times 10^{-8} \mathrm{~mol} / \mathrm{L}$ ) and then sterilized with a $0.22 \mu \mathrm{m}$ filter.

\subsection{Synthesis of the $T \alpha 1$ concatemer}

Two single strand DNA oligomers encoding the entire thymosin alpha peptide (synthesized by Songon, Shanghai, China.), partially complementary to each other (as indicated by the underlined sequences) were synthesized. We used codons that were preferred in E. coli.

THY-F: GTCGACATGGGATCCAACGGTTCTG A T G C T G C T G T A G A T A C T T C T T C T G A G A T TACTACTAAAGACCTAA

THY-R: CTCGAGTCAAGATCTCCCGTTCT CA G C C T C T T C G A C A A C T T C C T T C T T C T C C T TTAGGTCTTTAGTAGTA

The 2 oligonucleotides were mixed and denatured by incubation at $94^{\circ} \mathrm{C}$ for 10 minutes, and subsequently annealed at $60^{\circ} \mathrm{C}$ for 10 minutes in presence of TaqPlus (BBI, Toronto, Canada). The desired double-strand DNA was treated with T4 polynucleotide kinase (BBI, Toronto, Canada) and cloned into the cloning vector pUCm-T (BBI, Toronto, Canada).

The plasmid (pUCm-T-T $\alpha 1, \mathrm{pT}-\mathrm{T} \alpha 1$ ) containing the $T \alpha 1$ gene was digested with BamH I/Xho I or Bgl II/Xho I, respectively. The digested fragments containing the coding sequence of $\mathrm{T} \alpha 1$ were ligated with T4 DNA Ligase for 16 hours at $4^{\circ} \mathrm{C}$ to produce the concatemer $T \alpha 1$ gene of 2 repeats $(\mathrm{pT}-\mathrm{T} \alpha 1 \times 2)$. When the plasmid was digested with isocaudamer BamHI (G*CTAG C) and Bgl II (A*GATC T), the 2 fragments had similar termini. When the 2 fragments were catalyzed with T4 DNA Ligase the new sequence formed was GGATCT, and this new site could not be digested by BamH I or Bgl II (see Figure 2).

Using a $\mathrm{pT}-\mathrm{T} \alpha 1 \times 2$ plasmid, plasmids containing concatemer 4 repeats $(\mathrm{pT}-\mathrm{T} \alpha 1 \times 4)$ of the $T \alpha 1$ gene were prepared as described above. Using a $\mathrm{pT}-\mathrm{T} \alpha 1 \times 2$ plasmid and a $\mathrm{pT}$ -

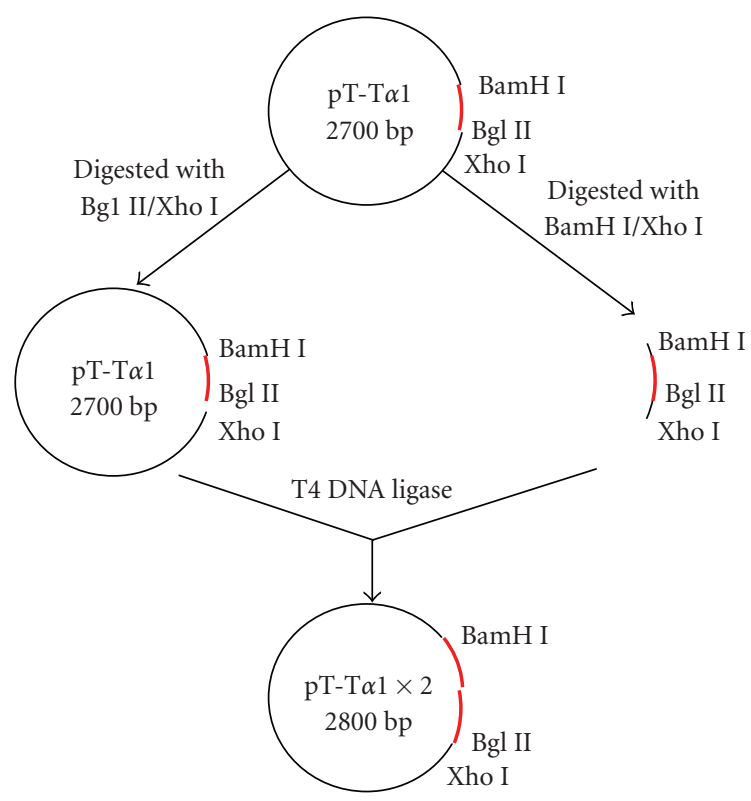

Red: $\mathrm{T} \alpha 1$ gene

Figure 2: Construction of the concatemer T $\alpha 1$ gene. A T-vector

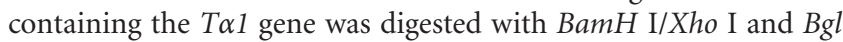
II/Xho I. When digested with Bgl II and BamH I, the 2 fragments have identical termini. The two fragments containing the $T \alpha 1$ gene were ligated with T4 DNA Ligase. A plasmid containing double T $\alpha 1$ genes was constructed. When the 2 fragments were catalyzed with T4 DNA Ligase, the new sequence formed was GGATCT, and this new site could not be digested by BamH I or Bgl II. Therefore, the new $2 \times$ concatemer gene could not be destroyed when the $4 \times$ concatemer gene was constructed. Thus, the plasmid containing $4 \times$, $6 \times T \alpha 1$ genes could also be constructed.

T $\alpha 1 \times 4$ plasmid, the preparation of plasmids containing concatemer 6 repeats $(\mathrm{pT}-\mathrm{T} \alpha 1 \times 6)$ was the same as $\mathrm{pT}$ $\mathrm{T} \alpha 1 \times 2$ plasmid.

Finally, a fragment containing the concatemer $T \alpha 1$ gene of 6 repeats was constructed and inserted into expression vector pET-22b $(+)$, between the restriction endonuclease recognition sites Hind III and Nde I.

\subsection{Expression and purification of $T \alpha 1$ concatemer protein}

A single bacterial colony containing pET-22b (+)-T $\alpha 1$ was grown overnight at $37^{\circ} \mathrm{C}$ in $5 \mathrm{~mL} \mathrm{LB}$ medium with $50 \mu \mathrm{g} / \mathrm{mL}$ 


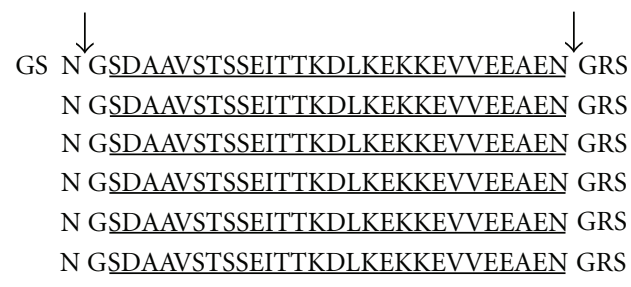

FIgURE 3: The sequence and hydroxylamine cleavage sites of the concatemer protein. The concatemer protein contained a total of 200 amino acids, and the molecular weight of the concatemer protein was approximately $23 \mathrm{kD}$. The $6 \times \mathrm{T} \alpha 1$ sequence is underlined, and the cleavage sites Asn-Gly are indicated with a vertical arrow.

Ampicillin (BBI, Toronto, Canada). The overnight culture was inoculated into $250 \mathrm{~mL}$ LB medium in a $1 \mathrm{~L}$ flask with $50 \mu \mathrm{g} / \mathrm{ml}$ Ampicillin. After 2 hours of incubation, isopropyl-1-thio-beta-D-galactoside (IPTG; BBI, Canada) was added to the culture at a final concentration of $1.0 \mathrm{mM}$, when the cell density had reached $\mathrm{OD}_{600 \mathrm{~nm}}=0.6$. After incubation at $37^{\circ} \mathrm{C}$ for 8 hours, the bacterial cells were harvested by centrifugation $(5000 \times g, 15$ minutes $)$ at $4^{\circ} \mathrm{C}$. The inducibility of the concatemer gene was determined by sodium dodecylsulfate-polyacrylamide gel electrophoresis (SDS-PAGE) (data not shown).

The cell pellet was resuspended in $100 \mathrm{~mL}$ buffer $\mathrm{A}$ (50 mM Tris-HCl [pH 8.0], 1 mM EDTA [pH 8.0], and $0.1 \mathrm{M} \mathrm{NaCl}$ ) and then sonicated ( $800 \mathrm{~W}, 20$ minutes). After sonication, the sedimented material (containing the concatemer protein) was washed once first with $100 \mathrm{~mL}$ buffer B (50 mM Tris-HCl [pH 8.0], 1 mM EDTA (pH 8.0), and $0.5 \%$ Triton-X 100) and then with $100 \mathrm{~mL}$ buffer $\mathrm{C}$ (50 mM Tris-HCl [pH 8.0], 1 mM EDTA (pH 8.0), and $2 \mathrm{M}$ urea) by centrifugation. The sedimented material was then dissolved in $100 \mathrm{~mL}$ buffer $\mathrm{D}$ (50 mM Tris- $\mathrm{HCl}$ [ $\mathrm{pH} 8.0$ ], $1 \mathrm{mM}$ EDTA [pH 8.0], and $8 \mathrm{M}$ urea) with stirring for 1 hour at $25^{\circ} \mathrm{C}$. The soluble protein was then dialyzed (Dialysis Membrane MWCO 10000 , SPECTRUM, Tex, USA) with double distilled $\mathrm{H}_{2} \mathrm{O}$ and cryodesiccated.

\subsection{Hydroxylamine cleavage reaction and analysis of cleavage products}

The concatemer protein was then cleaved with hydroxylamine. The cleavage sites are shown in Figure 3. The cleavage buffer [21] contained $0.1 \mathrm{M}$ trizma base and $2.0 \mathrm{M}$ hydroxylamine- $\mathrm{HCl}$. The $\mathrm{pH}$ of the cleavage buffer was adjusted with $5 \mathrm{M} \mathrm{NaOH}$ solution to a $\mathrm{pH}$ of 9.0, and the reaction was performed at $45^{\circ} \mathrm{C}$ for 4 hours. The reaction was terminated by adjusting the $\mathrm{pH}$ to 4.0 with concentrated formic acid and cooling to $4^{\circ} \mathrm{C}$ [21]. Using Sephadex-G25 (GE) column chromatography, the products of cleavage were desalted. Column chromatography revealed 2 peaks; one peak corresponded to the T $\alpha 1$ monomer and the other contained the incompletely cleaved concatemer protein. The molecular mass of the T $\alpha 1$ monomer was analyzed by GlySDS-PAGE and mass spectrometry.

\subsection{Assay for proliferation of mice splenic lymphocytes}

The proliferation response of splenocytes was determined by MTT assay [23]. Spleens were removed from mice and dispersed through nylon mesh to generate a single-cell suspension. Cells were pelleted $(1500 \times g, 6$ minutes $)$, and the cell pellet was resuspended in erythrocyte lysis solution $\left(0.15 \mathrm{M} \mathrm{NH}_{4} \mathrm{Cl}, 0.02 \mathrm{M}\right.$ Tris, sterilized with a $0.22 \mu \mathrm{m}$ filter) for 5 minutes to remove the red cells. After lysis, the cell suspension was incubated in a culture flask for 2 hours, and then the suspension was transferred to a new flask. Splenic macrophages adhered to the flask; this procedure enriched for lymphocytes.

Splenic lymphocytes were incubated in RPMI 1640 medium with $5 \mu \mathrm{g} / \mathrm{mL}$ concanavalin A (ConA; BBI, Canada) for 12 hours, and then harvested by centrifugation $(1500 \times$ $g$, 6 minutes). The cell pellet was resuspended in RPMI 1640 medium at a concentration of $1 \times 10^{6}$ cells $/ \mathrm{mL}$. A 96well culture plate (Costar, Inc., Calif, USA) was used for incubation of $180 \mu \mathrm{L}$ lymphocytes in RPMI 1640 medium. $50 \mu \mathrm{g} / \mathrm{mL}$ of the proteins (cleaved $\mathrm{T} \alpha 1$ and synthesized $\mathrm{T} \alpha \mathrm{l}$ ) were added to the wells. After 24-hour or 48-hour incubation at $37^{\circ} \mathrm{C}, 20 \mu \mathrm{L}$ of MTT $(0.5 \mathrm{mg} / \mathrm{mL})$, solution was added to each well, and the microplates were incubated for 4 hours at $37^{\circ} \mathrm{C}$. After incubation, the plates were centrifuged $(1400 \times$ $g, 18^{\circ} \mathrm{C}, 10$ minutes). The supernatants were removed, and $200 \mu \mathrm{L}$ of dimethyl sulfoxide (DMSO) was added to each well and incubated for 15 minutes at room temperature. After incubation, the solubilized reduced MTT was measured colorimetrically at $570 \mathrm{~nm}$ using a Benchmark microculture plate reader (Bio-Rad, Calif, USA).

\subsection{Assay for mitochondrial activity of HepG2 and SPC-A-1 cells}

The influence of $\mathrm{T} \alpha 1$ on mitochondrial activity was measured using MTT reduction, a common experimental method to quantify mitochondrial activity. The cells were seeded in a 96-well culture plate at $1 \times 10^{6}$ cells $/ \mathrm{mL}$. After 24-hour, 48-hour, and 72-hour exposures to $\mathrm{T} \alpha 1$ at a concentration of $0.1 \mathrm{mg} / \mathrm{mL}$, the cells were incubated with MTT $(0.5 \mathrm{mg} / \mathrm{mL})$ for 4 hours at $37^{\circ} \mathrm{C}$. The formazan precipitate was then dissolved in $200 \mu \mathrm{L} \mathrm{DMSO}$, and absorbance at $570 \mathrm{~nm}$ was measured using the Benchmark microculture plate reader (Bio-Rad, Calif, USA).

\subsection{Statistic analysis}

The data are presented as mean \pm SEM, for at least 3 replicate experiments and evaluated using the Student's $t$-test. $P$ values below 0.05 were regarded as statistically significance (two-tailed test).

\section{RESULTS}

Hydroxylamine-induced cleavage at the Asp-Gly dipeptide site inserted between the 2 moieties of recombinant fusion proteins had been used for both analysis and preparation of 


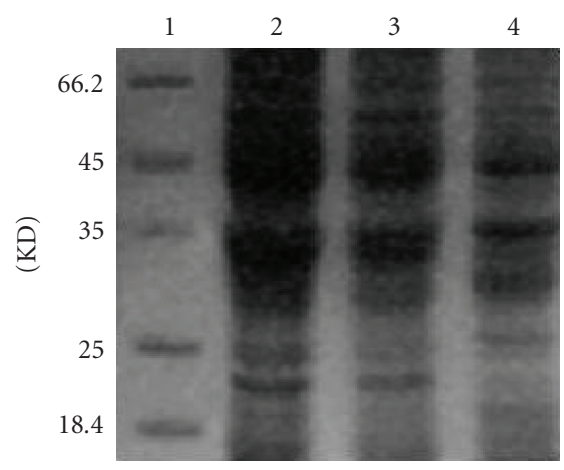

(a)

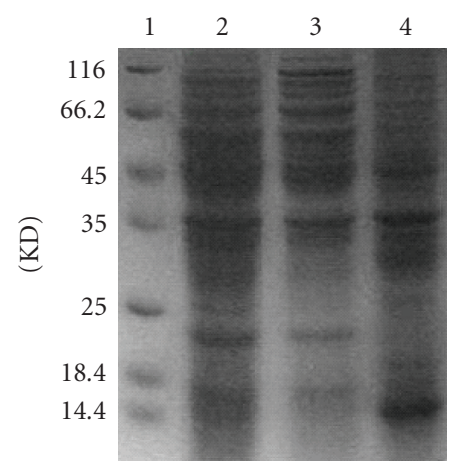

(b)

FIGURE 4: Overexpression of the recombinant concatemer protein. (a) Lane 1: prestained molecular mass markers. Lanes 2 and 3: full bacterial protein from $100 \mu \mathrm{L}$ transformed cells after $1.0 \mathrm{mM}$ and $0.5 \mathrm{mM}$ IPTG induction for 8 hours at $37^{\circ} \mathrm{C}$. Lane 4 : full bacterial protein from $100 \mu \mathrm{L}$ transformed cells without induction of IPTG for 8 hours at $37^{\circ} \mathrm{C}$. (b) Lane 1: prestained molecular mass markers. Lane 2: full bacterial protein from $100 \mu \mathrm{L}$ transformed cells after 1.0 mM IPTG induction for 8 hours. Lane 3: sedimented material from Sonication of $100 \mu \mathrm{L}$ transformed cells after induction with IPTG. Lane 4: suspended material from Sonication of $100 \mu \mathrm{L}$ transformed cells after induction with IPTG.

mature protein. Cleavage occurs at the Asn-Gly bonds and results from the tendency of the Asp side chain to cyclize the formation of a substituted succinimide that is susceptible to nucleophilic attack by hydroxylamine. The infrequency of Asn-Gly bonds in most proteins results in the production of very large fragments that may overlap CNBr-produced fragments [24]. In the complete amino acid sequence of T $\alpha 1$ [1] (see Figure 1), only 1 Asp was found at the C-terminus. However, the hydroxylamine-induced cleavage process was performed conveniently. Hydroxylamine-induced cleavage is high specificity and safe, however, the efficiency of hydroxylamine cleavage is low. So we expressed a concatemer protein of 6 repeats of $\mathrm{T} \alpha 1$ to increase the yield of $\mathrm{T} \alpha 1$ after cleavage and to decrease the cleavage sites.

\subsection{Characterization of recombinant concatemer protein}

The optimal conditions for inducing production of recombinant concatemer protein were at an IPTG concentration of $1.0 \mathrm{mM} 37^{\circ} \mathrm{C}$ for 8 hours. Under these conditions, the recombinant protein $(\sim 23 \mathrm{kD})$ comprised $31 \%$ of the total bacterial protein (see Figure 4(a)). The concatemer protein was identified primarily in the inclusion bodies (see Figure 4(b)).

\subsection{Analysis of the products of hydroxylamine cleavage}

G-25 column chromatography was used to not only desalt but also remove the incompletely cleaved concatemer protein. Because the molecular weight of the $\mathrm{T} \alpha 1$ monomer was $\sim 3.1 \mathrm{kD}$, it could enter the G-25 gel. However, the incompletely cleaved concatemer proteins, including $2 \times \mathrm{T} \alpha 1(\sim 7 \mathrm{kD}), 3 \times \mathrm{T} \alpha 1(\sim 11 \mathrm{kD}), 4 \times \mathrm{T} \alpha 1(\sim 15 \mathrm{kD}), 5 \times \mathrm{T} \alpha 1$ $(\sim 19 \mathrm{kD})$, and $6 \times \mathrm{T} \alpha 1(\sim 23 \mathrm{kD})$, could not enter the G25 gel because the gel only allows the entry of molecules $<5 \mathrm{kD}$. The Gly-SDS-PAGE could satisfactorily separate

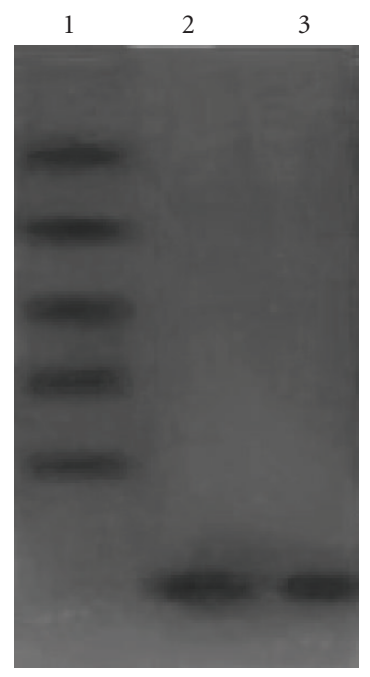

Figure 5: Analysis of hydroxylamine cleavage products. Lane 1: peak 1 of G-25 column chromatography revealed the protein with a molecular weight of more than $5 \mathrm{kD}$ that was eluted early. Lane 2: peak 2 of G-25 column chromatography containing the protein with a molecular weight of less than $5 \mathrm{kD}$ that was eluted later. Lane 3: the $\mathrm{T} \alpha 1$ synthesized as a standard protein.

polypeptides with molecular weights ranging from 3.5 to $68.0 \mathrm{kD}$ with good linearity, and demonstrated the successful hydroxylamine-induced cleavage of the concatemer proteins (see Figure 5). However, not all the concatemer proteins were cleaved, and the incompletely cleaved proteins could be completely cleaved by another reaction (data not shown).

MS was performed to analyze the exact molecular weights of the products and the synthesized T $\alpha 1$. The result showed that the products had only 1 peak of $\mathrm{m} / \mathrm{z}=1042.19$, while the synthesized $\mathrm{T} \alpha 1$ had 2 peaks of $\mathrm{m} / \mathrm{z}=1037.80$ and 1555.06 (see Figure 6). The molecular weight of the synthesized $\mathrm{T} \alpha 1$ was found to be approximately $3108 \mathrm{Da}$, it 


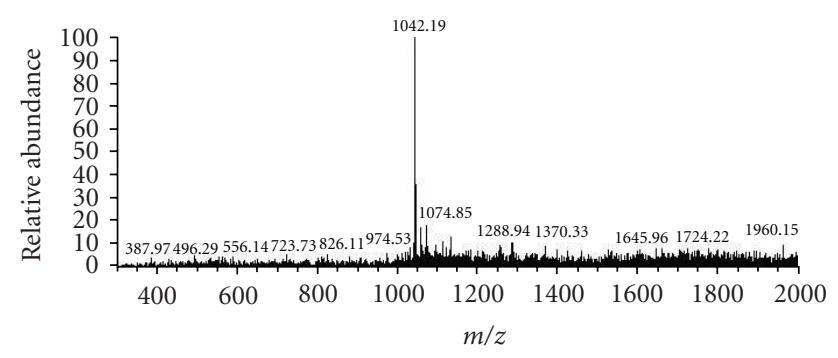

(a)

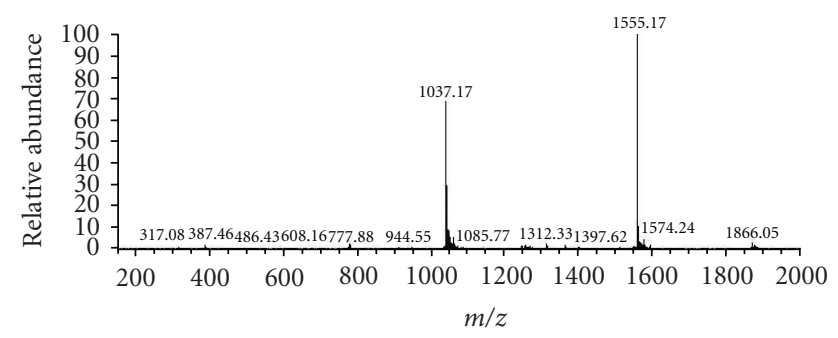

(b)

Figure 6: (a) Mass spectrum of the cleaved T $\alpha 1$. The attachment of 3 protons per peptide molecule leads to only 1 of $\mathrm{m} / \mathrm{z}$ peak; $\mathrm{m} / \mathrm{z}=$ 1042.19. (b) Mass spectrum of the synthesized T $\alpha 1$. The attachment of 2 and 3 protons per peptide molecule leads to 2 peaks of $\mathrm{m} / \mathrm{z}=$ 1037.80 and 1555.06 .

was assumed that the peptide might attach 2 or 3 protons [(1037.80-1) $\times 3=3110.4$; $(1555.06-1) \times 2=3108.12]$. Therefore, the cleaved $\mathrm{T} \alpha 1$ was believed to attach 3 protons, and the molecular weight of the products was approximately 3123.57 [(1042.19-1) $\times 3=3123.57]$. The difference in the molecular weights between the cleaved $\mathrm{T} \alpha 1$ and the synthesized $\mathrm{T} \alpha 1$ was approximately 15 . According to a previous research [24], the structural difference between the products and the synthesized $\mathrm{T} \alpha 1$ was a $-\mathrm{NH}$ added to the $\mathrm{N}$-terminus of the cleaved peptide (see Figure 9).

\subsection{T $\alpha 1$ cleaved by hydroxylamine stimulated the proliferation of mice splenic lymphocytes}

To determine the bioactivity of the T $\alpha 1$ monomer on lymphocyte proliferation, the mitochondrial activity was compared in the presence with the absence of the T $\alpha 1$. The bioactivity of T $\alpha 1$ preparations was analyzed by MTT assay. Preliminary results showed that the peptides could stimulate the mice spleen lymphocyte proliferation [22]. After a 24-hour treatment with $\mathrm{T} \alpha 1$ cleaved by hydroxylamine, mitochondrial activity was upgraded to $119.1 \%$ and after 48 hours, it was $110.4 \%$. The numbers of the synthesized T $\alpha 1$ were $117.5 \%$ and $116.0 \%$ at 24 hours and 48 hours, respectively (see Figure 7 ). Both of the peptide preparations could stimulate the proliferation of mice spleen lymphocytes to a similar degree.

\subsection{T $\quad 1$ cleaved by hydroxylamine exhibits decreased mitochondrial activity in SPC-A-1 and HepG2 cells}

In this study, we used human liver tumor cells HepG2 and human lung tumor cells SPC-A-1 as model, because the liver tumor and lung tumor are the most general tumor. To determine the role of mitochondria during incubation, the mitochondrial activity was examined. After the treatment with the cleaved T $\alpha 1$ for 24 hours, 48 hours, and 72 hours, the mitochondrial activity of the SPC-A-1 cells decreased to $82.4 \%, 27.1 \%, 11.6 \%$, respectively, and the corresponding activities with synthesized $\mathrm{T} \alpha 1$ were $62.0 \%, 15.1 \%$, and $9.8 \%$, respectively. On the other hand, after the treatment for 24 hours, 48 hours, and 72 hours, the mitochondrial activity of HepG2 cells decreased to $86.6 \%, 18.4 \%$, and
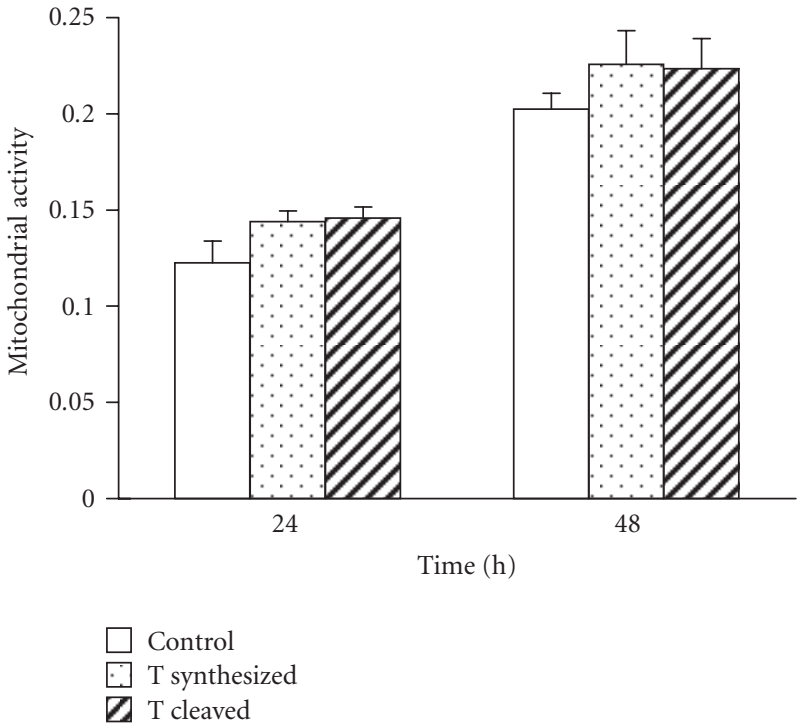

FIGURE 7: T $\alpha 1$ (cleaved and synthesized) stimulated the proliferation of mice spleen leukomonocytes. The mice spleen leukomonocytes were treated with the indicated concentrations of $\mathrm{T} \alpha 1$ for 24 hours, and 48 hours. MTT assay was used to measure the mitochondrial activity. Significant stimulation of the mitochondrial activity, as compared to the control, occurred after 48 hours of T $\alpha 1$ treatment. All the results are expressed as the mean \pm SEM of data obtained in 3 independent experiments $(P<.05$, relative to control).

$10.4 \%$, respectively, and corresponding activities with the synthesized $\mathrm{T} \alpha 1$ were $59.2 \%, 13.1 \%$, and $10.0 \%$, respectively (see Figure 8 ). Both of the peptide preparations decreased the mitochondrial activity remarkably, as compared to the control. The difference in the activity between the 2 peptides was not significant; however, the process of synthesizing T $\alpha 1$ was rather intricate.

\section{DISCUSSION}

The requirements of $\mathrm{T} \alpha 1$ for clinical applications are increasing. For clinical use, $\mathrm{T} \alpha 1$ is mainly obtained by chemical synthesis and animal thymus extraction. However, in fact, $\mathrm{T} \alpha 1$ from an animal is often impure and may therefore cause 


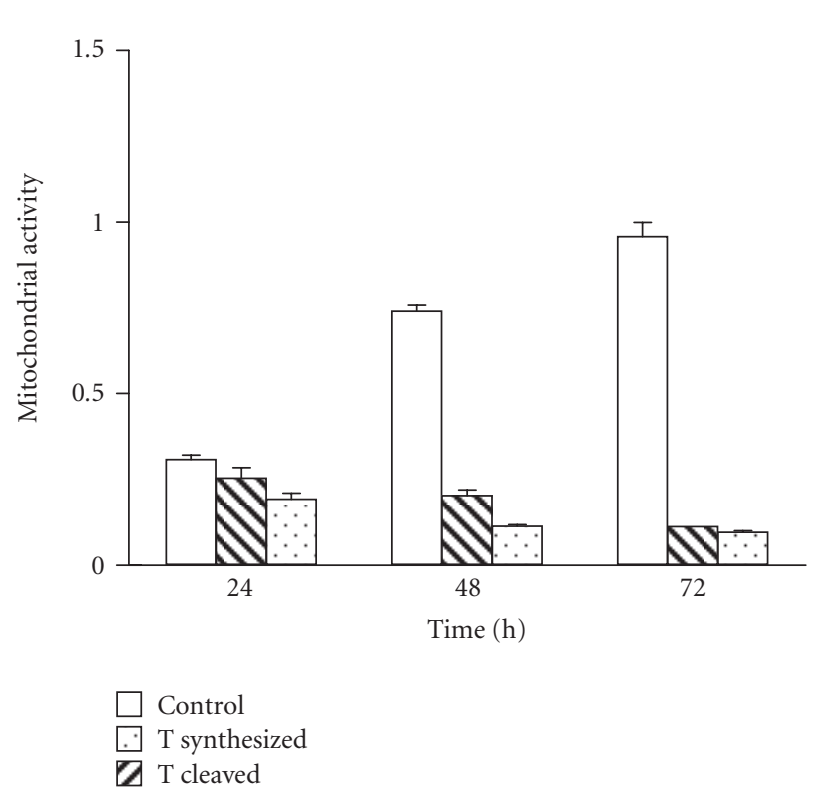

(a)
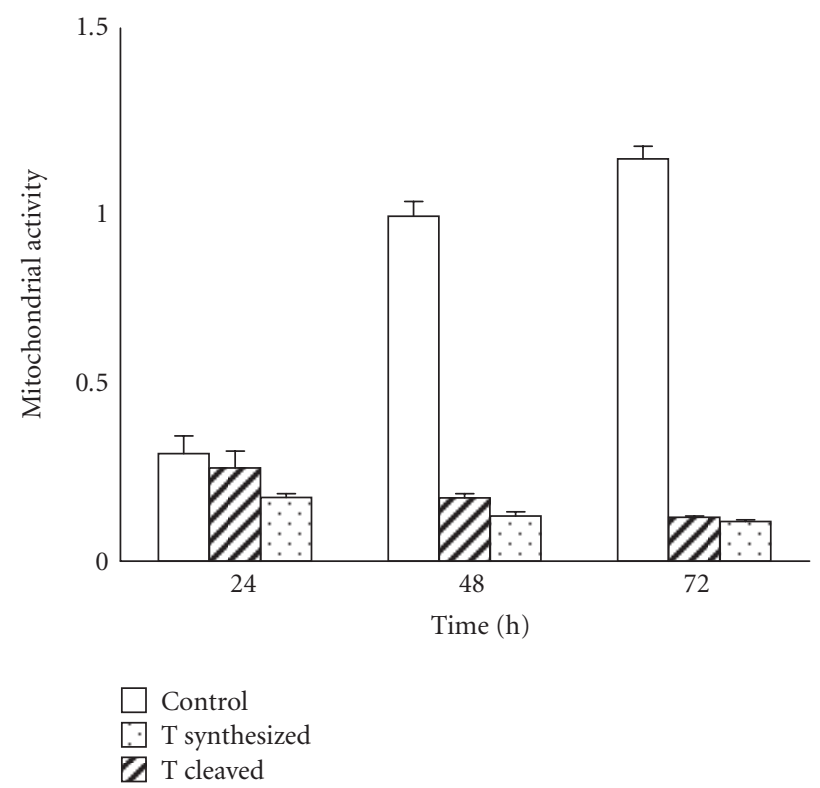

FIGURE 8: T $\alpha 1$ (cleaved and synthesized) induced a decrease in the mitochondrial activity in the SPC-A 1 and HepG2 cells. (a) The SPCA1 cells were treated with the indicated concentrations of T $\alpha 1$ for 24 hours, 48 hours, and 72 hours. MTT assay was used to measure the mitochondrial activity. Significant decreases in the mitochondrial activity, as compared to the control, occurred after 48 hours of T $\alpha 1$ treatment. (b) The HepG2 cells were treated with the indicated concentrations of T $\alpha 1$ for 24 hours, 48 hours, and 72 hours. MTT assay was used to measure the mitochondrial activity. Significant decreases in the mitochondrial activity, as compared to the control, occurred after 48 hours of T $\alpha 1$ treatment. All the results are expressed as the mean \pm SEM of data obtained in 3 independent experiments $(P<.05$, relative to control).

$$
\mathrm{NH}_{2}-\mathrm{CH}_{2}-\mathrm{CO}-\mathrm{T} \alpha 1 \quad \mathrm{CH}_{3}-\mathrm{CO}-\mathrm{T} \alpha 1
$$
(a) Cleaved $\mathrm{T} \alpha 1$
(b) Synthesized $\mathrm{T} \alpha 1$

FIgURE 9: Differences in the structures of the synthesized T $\alpha 1$ and the cleaved $\mathrm{T} \alpha 1$.

heterogeneous allergy. Although chemically synthesized T $\alpha 1$ can reach a high level of purity, it is necessary to eliminate the side products at each step, including incorrect joining and dextral compounds. The longer the peptide is, the more intricate the chemical synthesis process becomes. T $\alpha 1$ comprises 28 amino acid residues, and its chemical synthesis incurs a high production cost [19]. Prokaryotic expression systems allow for high expression of foreign genes and are widely used for producing large amounts of proteins or peptides. In this research, using a prokaryotic expression system BL21 (DE3)/pET-22b (+), we have established a new method to obtain relatively pure and large quantities of $\mathrm{T} \alpha 1$.

When the plasmid was digested with isocaudamer BamH $\mathrm{I}(\mathrm{G} * \mathrm{CTAG} \mathrm{C})$ and Bgl II (A*GATC T), the 2 fragments had similar termini. When the 2 fragments were catalyzed with T4 DNA Ligase, the new sequence formed was GGATCT, and this new site could not be digested by BamH I or Bgl II (see Figure 2). Therefore, the new $2 \times$ concatemer gene could not be destroyed when the $4 \times$ concatemer gene was constructed. The new site GGATCT corresponded to the dipeptide GlySer, located at the downstream of the $T \alpha 1$ gene. When concatemer protein was cleaved with hydroxylamine, the down- stream amino acid of $\mathrm{T} \alpha 1$ peptide was removed from this Gly site. When the cleavage reaction proceeded, the upstream amino acid of $\mathrm{T} \alpha 1$ peptide was removed from another Gly site, which was added in front of the T $\alpha 1$ peptide.

It is common knowledge that extraction of the micromolecular recombinant peptide from fermentation broth is difficult, when $T \alpha 1$ is expressed alone. Generally, a fusion protein is used under these circumstances, for example, a DsbA fusion protein [25]. However, the fusion protein must be removed because the peptide might be inactive, and this process incurs a high production cost. The concatemer protein of 6 repeats- $6 \times \mathrm{T} \alpha 1$-was prepared in this research to avoid the use of a fusion protein when expressing the recombinant protein, but the number of the repeats was not unique. Proteins with 4, 8, 12, and so forth repeats could also be constructed. The longer the concatemer protein is, the greater the yield of the T $\alpha 1$ monomer is. On the other hand, when a concatemer protein with more repeats is cleaved, the amount of the incompletely cleaved protein also increases (see Figure 5). However, these incompletely cleaved proteins can be cleaved by other 1 or 2 rounds of hydroxylamine cleavage.

Hydroxylamine was used to cleave the Asn-Gly peptide bond between the fusion protein and target protein [26]. In this study, hydroxylamine was used to cleave the concatemer protein of $6 \times \mathrm{T} \alpha 1$ to release the $\mathrm{T} \alpha 1$ monomer. While chemical cleavage methods use relatively inexpensive and widely available reagents, cleavage conditions are often relatively harsh and amino acid side-chain modifications 
may occur. This is especially true when hydroxylamine is used to cleave the Asn-Gly peptide linkages as other Asn or Gln residues can be modified to their hydroxamic acid forms [26]. Because the T $\alpha 1$ peptide does not contain Gln, Met, or other Asn, chemical heterogeneity dose not occur by conversion of the Gln or Asn to their hydroxamate forms. Moreover, there is no possibility of chemical heterogeneity by conversion of Met to its oxidized forms [27].

After hydroxylamine cleavage, a Gly remained at the $\mathrm{N}$-terminus of $\mathrm{T} \alpha 1$. However, the natural $\mathrm{T} \alpha 1$ had an acetylated NH-terminal (see Figure 9). The molecular weight difference between the 2 groups was $15 \mathrm{Da}$, but there was no significant difference between the 2 bands revealed by the Gly-SDS-PAGE (see Figure 5). Hence, we used an MS to analyze the exact molecular weights of the 2 peptides. The result showed a difference was $15 \mathrm{Da}(3123-3108 \mathrm{Da}$ ) (see Figure 6), indicating that the concatemer protein was cleaved satisfactorily.

To investigate the influence of the extra imino group on the $\mathrm{T} \alpha 1$, we compared the antitumor and immunomodulation activities between the synthesized $\mathrm{T} \alpha 1$ and the cleaved $\mathrm{T} \alpha 1$. The results showed no significant difference between the 2 peptides. Furthermore, we found that $\mathrm{T} \alpha 1$ was able to depress the prolife ration of HepG2 cells by downregulating the oxidative stress (data not shown). Jörnvall [28] had analyzed 40 known $\alpha$-amino-acetylated polypeptide chains and postulated that acetylation occurs during an early posttranslational stage and may have particular importance in this regard. However, the structural or functional significance of the $\mathrm{N}$-terminal acetylation of $\mathrm{T} \alpha 1$ is not known, and a protective function of acetylation with regard to proteolysis is possible [1]. The change in the $\mathrm{N}$-terminus of cleaved peptides might not influence the bioactivity of $\mathrm{T} \alpha 1$; however, it might influence the stability in vivo.

In summary, $\mathrm{T} \alpha 1$ with a novel structure was prepared via the expression and hydroxylamine cleavage of a T $\alpha 1$ concatemer protein. This novel T $\alpha 1$ could perform proliferation of mice splenic lymphocytes activities, identical to the natural $\mathrm{T} \alpha 1$. This study would provide the basis for the preparation of active $\mathrm{T} \alpha 1$ and other peptides.

\section{ACKNOWLEDGMENT}

This work was supported by a grant from National Innovation Fund for Technology, the Ministry of Science and Technology of China (no. 03C26213300586).

\section{REFERENCES}

[1] A. L. Goldstein, T. L. K. Low, M. McAdoo, et al., "Thymosin $\alpha_{1}$ : isolation and sequence analysis of an immunologically active thymic polypeptide," Proceedings of the National Academy of Sciences of the United States of America, vol. 74, no. 2, pp. 725729, 1977.

[2] T. L. K. Low, G. B. Thurman, M. McAdoo, et al., "The chemistry and biology of thymosin. I. Isolation, characterization, and biological activities of thymosin $\alpha_{1}$ and polypeptide $\beta_{1}$ from calf thymus," The Journal of Biological Chemistry, vol. 254, no. 3, pp. 981-986, 1979.
[3] C. S. Sarandeses, G. Covelo, C. Díaz-Jullien, and M. Freire, "Prothymosin $\alpha$ is processed to thymosin $\alpha_{1}$ and thymosin $\alpha_{11}$ by a lysosomal asparaginyl endopeptidase," The Journal of Biological Chemistry, vol. 278, no. 15, pp. 13286-13293, 2003.

[4] A. P. Knutsen, J. J. Freeman, K. R. Mueller, S. T. Roodman, and J. D. Bouhasin, "Thymosin- $\alpha 1$ stimulates maturation of $\mathrm{CD}_{3}{ }^{+}$stem cells into $\mathrm{CD}^{+} 4^{+}$cells in an in vitro thymic epithelia organ coculture model," International Journal of Immunopharmacology, vol. 21, no. 1, pp. 15-26, 1999.

[5] K. D. Leichtling, S. A. Serrate, and M. B. Sztein, "Thymosin alpha 1 modulates the expression of high affinity interleukin2 receptors on normal human lymphocytes," International Journal of Immunopharmacology, vol. 12, no. 1, pp. 19-29, 1990.

[6] J. A. Moshier, M. G. Mutchnick, J. Dosescu, et al., “Thymosin$\alpha_{1}$, but not interferon- $\alpha$, specifically inhibits anchorageindependent growth of hepatitis B viral transfected HepG2 cells," Journal of Hepatology, vol. 25, no. 6, pp. 814-820, 1996.

[7] D. Bianco-Batlles, C. W. Naylor, J. A. Moshier, J. Dosescu, and P. H. Naylor, "Clonal growth inhibition as a bioassay for thymosin alpha1: inactivation of T $\alpha 1$ by trifluroacetic acid," Cellular and Molecular Biology, vol. 47, no. 1, pp. 157-160, 2001.

[8] C. A. Baumann, M. Badamchian, and A. L. Goldstein, "Thymosin $\alpha_{1}$, antagonizes dexamethasone and CD3-induced apoptosis of $\mathrm{CD}^{+}{ }^{+} \mathrm{CD} 8^{+}$thymocytes through the activation of cAMP and protein kinase $\mathrm{C}$ dependent second messenger pathways," Mechanisms of Ageing and Development, vol. 94, no. 1-3, pp. 85-101, 1997.

[9] R. Roy, S. M. Singh, and A. Shanker, "Mechanism of thymocyte apoptosis induced by serum of tumor-bearing host: the molecular events involved and their inhibition by thymosin $\alpha$ 1," International Journal of Immunopharmacology, vol. 22, no. 4, pp. 309-321, 2000.

[10] J. Beuth, J. M. Schierholz, and G. Mayer, "Thymosin $\alpha_{1}$ application augments immune response and down-regulates tumor weight and organ colonization in BALB/c-mice," Cancer Letters, vol. 159, no. 1, pp. 9-13, 2000.

[11] C. Giuliani, G. Napolitano, A. Mastino, et al., "Thymosin$\alpha 1$ regulates MHC class I expression in FRTL-5 cells at transcriptional level," European Journal of Immunology, vol. 30, no. 3, pp. 778-786, 2000.

[12] Y. Huang, Z. Chen, C. Zhou, H. Yao, M. Li, and C. Xu, "The modulation of thymosin alpha 1 in the maturation, differentiation and function of murine bone marrow-derived dendritic cells in the absence or presence of tumor necrosis factor- $\alpha$, International Immunopharmacology, vol. 4, no. 4, pp. 539-546, 2004.

[13] E. Tzehoval, M. B. Szteiu, and A. L. Goldstein, "Thymosius $\alpha_{1}$ and $\beta_{4}$ potentiate the antigen-presenting capacity of macrophages," Immunopharmacology, vol. 18, no. 2, pp. 107113, 1989.

[14] J. W. Hadden, “Thymic endocrinology," Annals of the New York Academy of Sciences, vol. 840, pp. 352-358, 1998.

[15] G. Rasi, P. Pierimarchi, P. Sinibaldi Vallebona, F. Colella, and E. Garaci, "Combination therapy in the treatment of chronic viral hepatitis and prevention of hepatocellular carcinoma," International Immunopharmacology, vol. 3, no. 8, pp. 11691176, 2003.

[16] S. Moscarella, G. Buzzelli, R. G. Romanelli, et al., "Interferon and thymosin combination therapy in naive patients with chronic hepatitis C: preliminary results," Liver, vol. 18, no. 5, pp. 366-369, 1998. 
[17] E. Garaci, F. Pica, G. Rasi, and C. Favalli, "Thymosin alpha 1 in the treatment of cancer: from basic research to clinical application," International Journal of Immunopharmacology, vol. 22, no. 12, pp. 1067-1076, 2000.

[18] A. Billich, "Thymosin $\alpha 1$ : SciClone Pharmaceuticals," Current Opinion in Investigational Drugs, vol. 3, no. 5, pp. 698-707, 2002.

[19] P.-F. Chen, H.-Y. Zhang, G.-F. Fu, G.-X. Xu, and Y.-Y. Hou, "Overexpression of soluble human thymosin alpha 1 in Escherichia coli," Acta Biochimica et Biophysica Sinica, vol. 37, no. 2, pp. 147-151, 2005.

[20] S. Yi, A. Brickenden, and W.-Y. Choy, "A new protocol for high-yield purification of recombinant human prothymosin $\alpha$ expressed in Escherichia coli for NMR studies," Protein Expression and Purification, vol. 57, no. 1, pp. 1-8, 2008.

[21] H.-B. Park, S.-H. Pyo, S.-S. Hong, and J.-H. Kim, “Optimization of the hydroxylamine cleavage of an expressed fusion protein to produce a recombinant antimicrobial peptide," Biotechnology Letters, vol. 23, no. 8, pp. 637-641, 2001.

[22] Y. Chen, L. Zhao, G. Shen, et al., "Expression and analysis of thymosin $\alpha 1$ concatemer in Escherichia coli," Biotechnology and Applied Biochemistry, vol. 49, no. 1, pp. 51-56, 2008.

[23] L. Qiu, B. Y. Guo, H. Miao, et al., "Study on biological function of prothymosin a and its DNA microarray analysis," Academic Journal of Second Military Medical University, vol. 23, no. 6, pp. 639-642, 2002.

[24] P. Bornstein and G. Balian, "Cleavage at Asn-Gly bonds with hydroxylamine," Methods in Enzymology, vol. 47, pp. 132-145, 1977.

[25] C. Lin, X. Li, P. Wang, and J. Mei, "Construction and expression of recombinant human thymosin alpha 1," Journal of Zhejiang University of Technology, vol. 33, no. 3, pp. 306309, 2005.

[26] M. Antorini, U. Breme, P. Caccia, et al., "Hydroxylamineinduced cleavage of the asparaginyl-glycine motif in the production of recombinant proteins: the case of insulin-like growth factor I," Protein Expression and Purification, vol. 11, no. 1, pp. 135-147, 1997.

[27] S. J. Milner, S. M. Thomas, F. J. Ballard, and G. L. Francis, "Optimization of the hydroxylamine cleavage of an expressed fusion protein to produce recombinant human insulin-like growth factor (IGF)-I," Biotechnology and Bioengineering, vol. 50, no. 3, pp. 265-272, 1996.

[28] H. Jörnvall, "Acetylation of protein N-terminal amino groups structural observations on $\alpha$ amino acetylated proteins," Journal of Theoretical Biology, vol. 55, no. 1, pp. 1-12, 1975. 

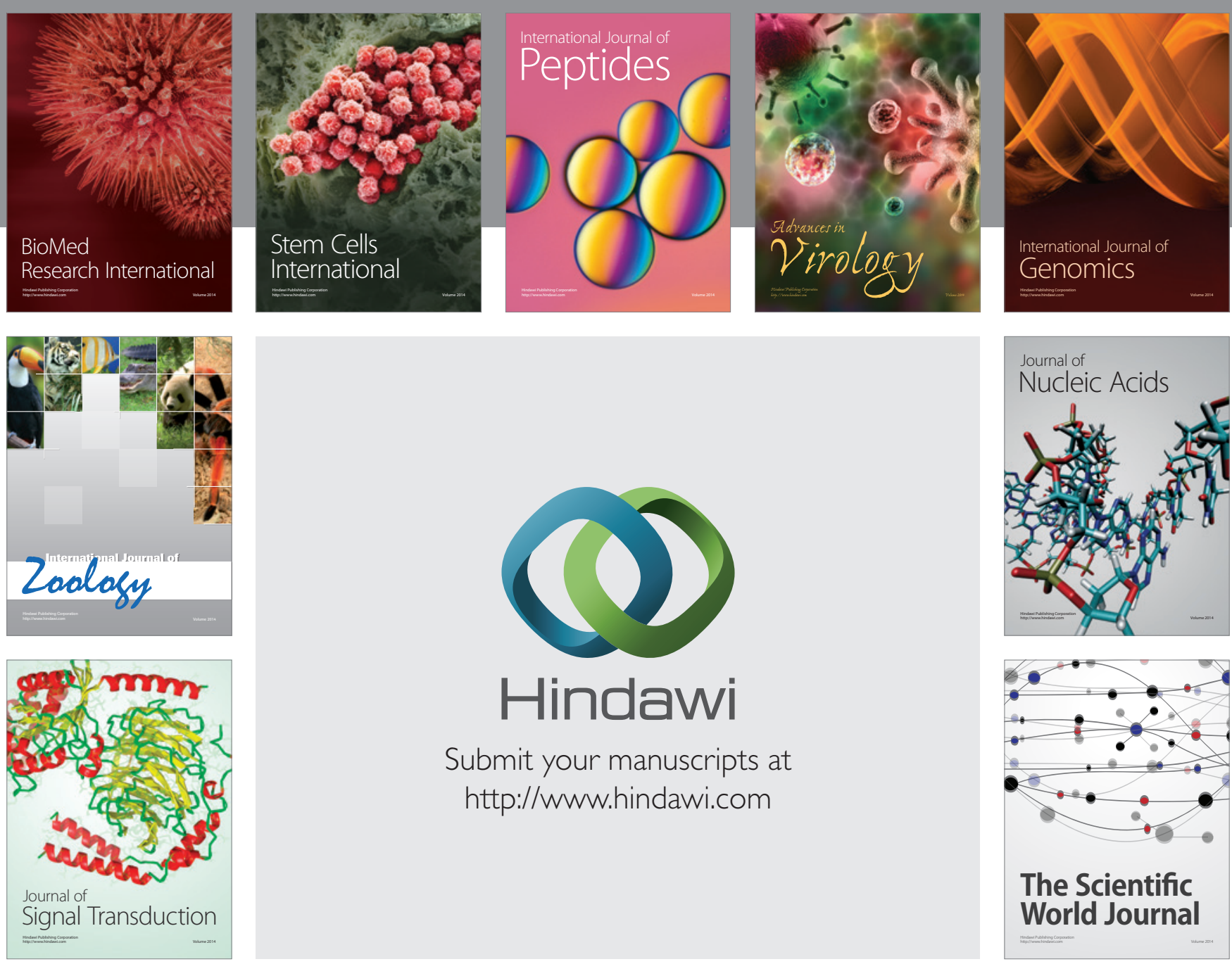

Submit your manuscripts at

http://www.hindawi.com
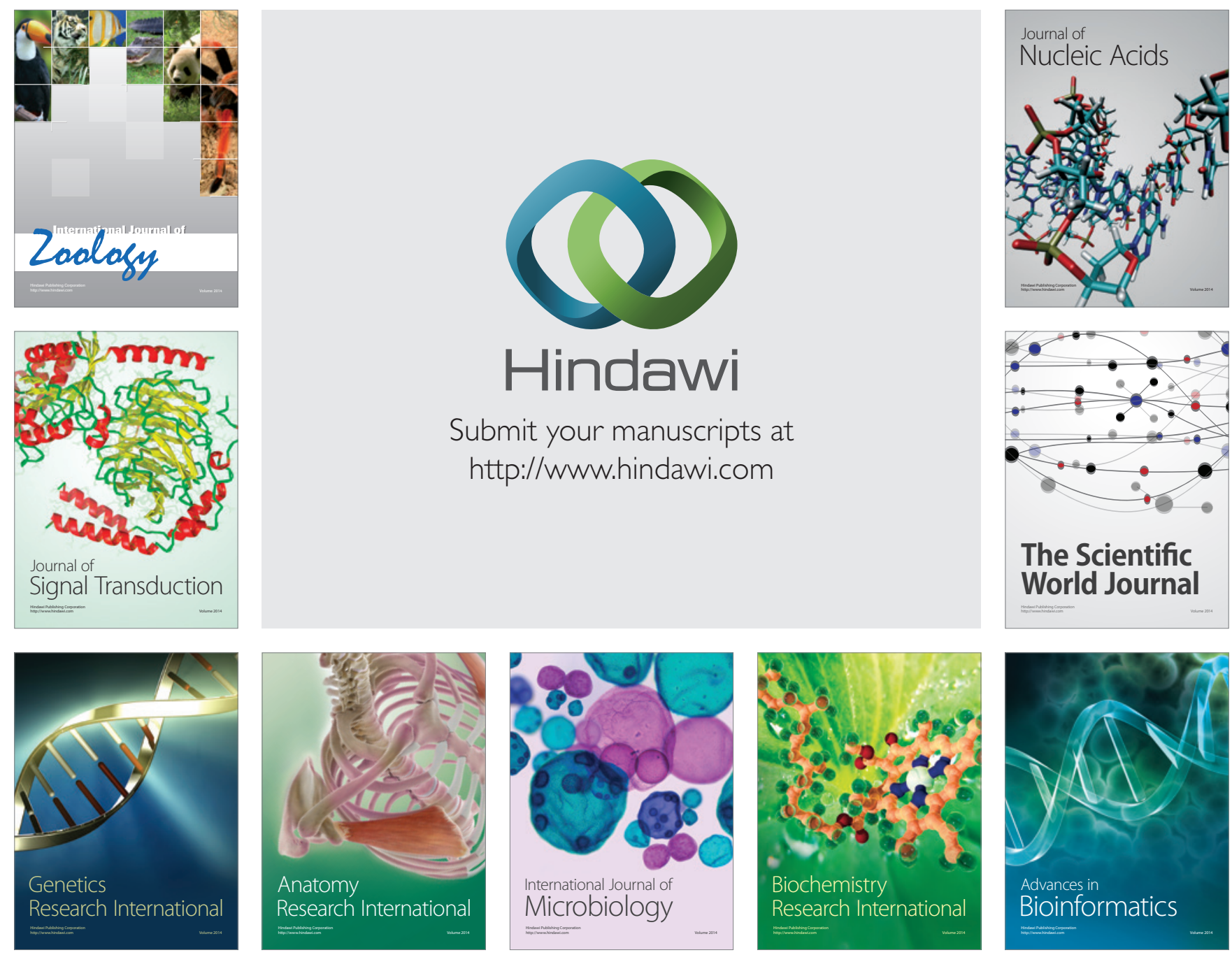

The Scientific World Journal
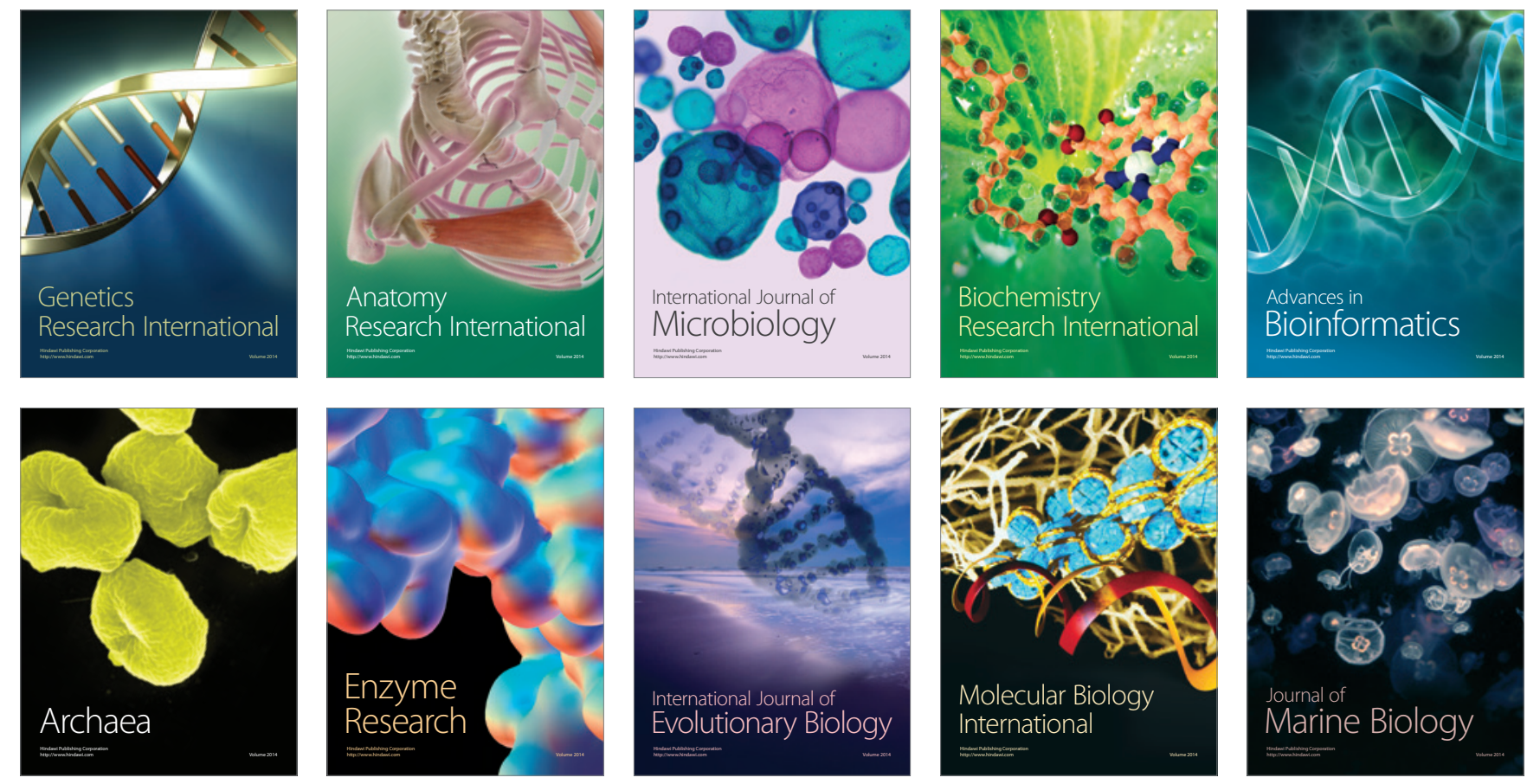